\title{
Effect of Shading and Mowing on the Growth of Indonesia's Native Zoysia grass in Silty Clay Soil
}

\author{
Rahayu $^{1 *}$, Mujiyo1, Randy Ramadhan ${ }^{1}$, Geun Mo Yang ${ }^{2}$ and Joon Soo Choi ${ }^{2}$ \\ ${ }^{1}$ Department of Soil Science, Faculty of Agriculture, Universitas Sebelas Maret, Surakarta, Indonesia; \\ ${ }^{2}$ Architecture Landscape Bio Resource Science Dankook University, South Korea \\ *Corresponding author: rahayu_uns@yahoo.co.id
}

\begin{abstract}
In general, turfgrass grows well and forms high quality turf under full sun exposure. It is very difficult, however, to grow a warm season turfgrass under shaded condition. Zoysia grass is a popular warm season grass that commonly grow under full sun exposure condition. There are limited information regarding the growth response and turf quality of zoysia grass when grown under shaded condition. This study aims to observe the growth and quality of various zoysia grass local cultivars at different shading intensities and different mowing. This research was carried out using 10 zoysia grass cultivars planted in the rice fields' vertisol clay with randomized complete block design. The shading used were control, shade-nets with $25 \%$ and $65 \%$ hole densities. Zoysia grass was fertilized using NPK; 4:1:3 and mowed three times. The results showed that plants without shade, $25 \%$ and $65 \%$ received on average solar irradiance of 25,141; 12,456 and 3,727 lux. The increase in shade level decreased the shoot fresh weight, dry weight, root dry weight and the plant height. Shading and frequent mowing effected the plant height. Mowing has more effect on plant height in $25 \%$ shading than in $65 \%$ shading. The increase in shading, in mowed grass showed increased plant height and decreased plant dry weight. Mowing three times can reduce plant height in all shades. The grasses under $25 \%$ shading resulted the highest plant dry weight; whereas and shading $65 \%$ resulted the lowest. Plant dry weight and uniformity of turf were affected by the cultivars.
\end{abstract}

Keywords: growth; mowing; shading; zoysia grass

Cite this as: Rahayu, Mujiyo, Ramadhan, R., Yang, G. M., \& Choi, J. S. (2020). Effect of Shading and Mowing on the Growth of Indonesia's Native Zoysia grass in Silty Clay Soil. Caraka Tani: Journal of Sustainable Agriculture, 35(2), 317-325. doi: http://dx.doi.org/10.20961/carakatani.v35i2.40303

\section{INTRODUCTION}

Turfgrass is important plant for human living since it serves as ornamental plant, it protects the soil surface from erosions and gives bedding function for playgrounds and sport activities. Turfgrass has high potentials to reduce runoff, increase infiltration, purify water from sediments and pollutants and to control erosion (Monteiro, 2017). Sustainable agriculture can be achieved by recovering the natural vegetations since revegetation could increase aggregate stability and decrease soil erodibility (An et al., 2013). Zoysia grass middle and coarse leaves were potential in improving soil aggregate stability (Rahayu et al., 2020). However, growing grasses on clay growing media is very difficult. Turfgrass decreases in shoot density and root dry weight and total root length when there is an increase in the compaction in the top $21 \mathrm{~cm}$ of clay layer (Lakshmipathy et al., 2018). Tree canopy in urban green spaces promotes surface litter accumulation and increase soil $\mathrm{C} / \mathrm{N}$, compared to short turfgrass surface (Livesley et al., 2016). However, turfgrass

\footnotetext{
* Received for publication February 25, 2020

Accepted after corrections August 8, 2020
} 
commonly shows good turf when it is grown under full sun exposure condition.

Growing turfgrass in shaded sites requires harder management practices than turf in full sun sites. Most of turfgrasses grow well and show good turf under sunny condition and the opposite happened in low light level, which resulted in low turf quality. Shades reduce solar radiation and it affects the microclimate in the turf grows area (Beard, 1997). Under shades, turfgrass' growth is inhibited due to the reduction in photosynthesis and carbon production, lateral stem growth and existing competition between the turfgrass and the tree root (Baldwin et al., 2007). Turfgrass grown under shaded conditions suffers from reduced photosynthesis (Qian et al., 1998). Shade condition reduces zoysia grass photosynthesis and results in reduced turfgrass aesthetic quality (Bradley et al., 2009). Shade's conditions reduce the turf quality until of an estimated $20 \%$ to $25 \%$ of all turfs (Dudeck and Peacock, 1992) and reduced tillering (Okeyo et al., 2014) thus the density and quality became low. Lower light conditions contributed to less green coverage, because tree leaves filtered the photosynthetically important red and blue wavelengths sunrays before they reach the turfgrass surface. However the capability of turfgrass to produce stolon under dense shade have contribution in the ability of zoysia grasses to produce green coverage (Peterson et al., 2014).

Zoysia spp. is a grass species which is widely in the tropical area especially in Indonesia and it has the potentials to be used in parks, golf courses, football fields and home lawns. Zoysia grass is a sod-forming warm-season turfgrass which is indigenous to the Pacific Rim (Anderson, 2000). However there are zoysia natives in Indonesia (Rahayu et al., 2016). In total there are 11 species' of the Zoysia genus and three of them are used as a turfgrass: Zoysia japonica, Zoysia matrella and Zoysia pacifica (Engelke and Anderson, 2003). Leaf width is the defining characteristic of a turfgrass texture. Commonly Zoysia japonica have coarser texture than texture of Zoysia matrella and Zoysia pacifica (Fry et al., 2008). Zoysia grass has been identified as one of the lower-maintenance species for further development that can be managed with low inputs of fertilizers, water and chemicals for pest control (Beard, 1973). Thus it a desirable choice in many region (Fry and Huang, 2004). Among
Zoysia grass species there are variation in term of shade tolerance. Zoysia japonica performs poorly under moderate to dense shade (Sladek et al., 2009). Whereas Zoysia matrella species is commonly more shade-tolerant than Zoysia japonica species (Wherley et al., 2011). In Italy, Zoysia matrella has been classified as a casual plant and a newcomer plant (Celesti-Grapow et al., 2009).

Sun rays is utilized by plants in photosynthesis process. The intensity of the light affects the rate of photosynthesis which manifested in plant growth. Under shaded condition the plants' photosynthesis rate is decreased due to low light intensity, quantity and quality and resulted in reduced turf quality (Patton, 2009). Increase in the threes' age will increase the shade coverage and in the end it will reduce the level of light intensity accepted by turf (Wijayanto and Nurunnajah, 2012). The intensity of light required by the young plants is lower than by older plants (Faridah, 1996). Different plant species have different rate of responses to the intensity of sunlight received (Audina et al., 2016). Different zoysia grass genotypes has different shade tolerance (Patton, 2009). Performance of zoysia grass under $90 \%$ shade was reported to be poor with minimal soil surface coverage and low aesthetic quality. However, establishing zoysia grass by plugs under $50 \%$ shade condition remains feasible through the use of several improved genotype (Bradley et al., 2009).

Plants reaction to the solar radiation intensity are different according to the species, i.e. full sun plants or shade plants. Plants grown in full sun conditions tend to have higher root dry weight than under shaded conditions (Alvarenga et al., 2004). Tolerant shade plants can accumulate photosynthesis products with low light levels compared to full light plants (Pantilu et al., 2012). Under shaded condition, the turfgrasses maintenance need limbs pruning, reduced fertilization, increased mowing height, leaves removal and applying plant growth regulators (Patton, 2009). Shaded turfs require less fertilization because they grow slowly; hence, the fertilization should be decreased by half (Patton, 2009). Based on the addressed problems, it is necessary to study the effect of light intensity on the visual and functional quality parameters of Zoysia sp. growth in order to get the best crop yield in shade test. 


\section{MATERIALS AND METHOD}

The experiment was conducted from February to August 2017. The grasses were planted in rice field at $7^{\circ} 36^{\prime} 53^{\prime \prime}$ South Latitude; $110^{\circ} 51^{\prime} 03^{\prime \prime}$ East Longitude in Mojolaban Sub-district, Sukoharjo, Central Java-Indonesia, where the soil was silty clay and belong to vertisols. The experimental design was Randomized Complete Block Design method with two replicates. The factors were shades and Zoysia cultivars. The grass was fertilized using NPK ratio of $4: 1: 3$ with dosage $5 \mathrm{~g} \mathrm{~N} \mathrm{~m}^{-2}$ and was applied every month.

The turfgrasses were Indonesian native wild type Zoysia grass of 10 cultivars. The cultivars were obtained from road side of Bogor, sea side of Jepara, sea side of Kebumen, road side of Kepuh Harjo Sleman, soccer field of Klaten, tourism area of Prambanan Sleman, soccer field of Solo 1 as fine texture, from filed of Solo 2 as medium texture, sea side of Tabanan Bali and sea side of Ternate. The zoysia grass were propagated using stolon. Within every point of soil three stolon were planted, every stolon was as long as 3 nodes. The space between planting point was $7 \mathrm{~cm}$ and the plot size was $1 \mathrm{~m} \mathrm{x} 1 \mathrm{~m}$.

The shading treatments were $0 \%$ (I0) as full sun, $25 \%$ shading with plastic shade-nets in black color (I1) and 65\% shading with plastic shadenets (I2). Each of the soil plot were divided into six rows for planting grass with a wide $1 \mathrm{~m}$ and long $10 \mathrm{~m}$ each row. The shade-nets was covering the turfgrass with $1 \mathrm{~m}$ high above the soil surface. The light intensity during day was measured using solar radiation calculator Lux App, downloaded from google play store. The measurements of the solar radiation were conducted in the morning at $9.00 \mathrm{am}$, afternoon at $12.00 \mathrm{am}$ and evening at $15.00 \mathrm{pm}$ every 3 days for 6 weeks. The turfgrasses were mowed for the length of $3 \mathrm{~cm}$ started after the soil surfaces were $100 \%$ covered by the grasses. The mowing were continued periodically with 14 days interval. During the experiment, the grasses were irrigated using fresh water with 3 days interval.

The observed variable was turfgrass growth, including plant height every week, tiller density, color score, shoot weight after mowing. The root length and weight were measured after 6 months; recovery after low mowing was observed every 14 days for 3 times; whereas leaf texture was observed every month. Plant height was measured from the base of the stem to the tip of the highest grass leaves. The data was analyzed by using Anova with significance level equal to 0.05 . Significant results were then tested using Duncan Multiple Range Test (DMRT) with 95\% confidence level.

\section{RESULTS AND DISCUSSION}

The soil characteristics in this study was neutral with $\mathrm{pH}$ of 7.0. Normally, the $\mathrm{pH}$ of vertisol is neutral to alkali (Syers et al., 2001). This soil was also considered as fertile since it has organic matter content of $2.03 \%$ and cation exchange capacity (CEC) of $25.1 \mathrm{meq} 100 \mathrm{~g}^{-1}$ (Table 1). Table 2 showed that the control pot received solar intensity of 25,141 lux on average; almost doubled when compared to the treatment with $25 \%$ of shade-nets which solar intensity was 12,456 lux. The treatments with $65 \%$ shading received solar intensity of about 3,727 lux or approximately $14.8 \%$ of the control. Results also showed that morning time had higher solar intensity than in the evening. Zoysia grass cultivars have leaf texture from narrow $(28 \mathrm{~mm})$ to medium texture $(43 \mathrm{~mm})$. There were no differences in the color, fresh weight and root length of the grasses with shading treatments; but there were variations in plant height, tiller density, recovery percentage and dry weight (Table 3).

Table 1. Characteristics of Vertisol soil

\begin{tabular}{lcc}
\hline \multicolumn{1}{c}{ Characteristics } & Unit & Value \\
\hline $\mathrm{pH} \mathrm{H}_{2} \mathrm{O}$ & & 7.00 \\
$\mathrm{C}$ Organic & $\%$ & 1.59 \\
Organic Matter & $\%$ & 2.03 \\
$\mathrm{CEC}$ & ${\mathrm{meq} 100 \mathrm{~g}^{-1}}^{-1}$ & 25.10 \\
$\mathrm{ECp}$ & $\mathrm{dS} \mathrm{m}^{-1}$ & 1.55 \\
Texture & & silty clay \\
Sand & $\%$ & 26.00 \\
Silt & $\%$ & 42.00 \\
Clay & $\%$ & 32.00 \\
\hline
\end{tabular}

The initial leaf width before mowing ranges from coarse to very coarse. Very coarse leaf texture was found on the cultivar of Zoysia spp from Jepara with $4.25 \mathrm{~mm}$. Whereas the least coarse leaf texture was obtained from Tabanan Bali cultivar with $3.75 \mathrm{~mm}$; which was categorized as coarse fineness. Genetically, shade tolerant crops have high adaptability to 
environmental changes. The increase in leaf area is an effort to capture of light energy efficiently for normal photosynthesis under conditions of lack of light (Asriyanti and Irmasari, 2015).

Table 2. Solar intensity during research in 3 different shading percentage

\begin{tabular}{ccccc}
\hline Shade-net & \multicolumn{4}{c}{ Solar intensity $(\mathrm{lux} \pm \mathrm{SD})$} \\
\cline { 2 - 5 } treatment & Morning (09.00 am) & Afternoon (12.00 am) & Evening (15.00 pm) & Total \\
\hline $0 \%$ & $23,476 \pm 2,008$ & $39,131 \pm 3,139$ & $12,816 \pm 948$ & $25,141 \pm 2,357$ \\
$25 \%$ & $10,435 \pm 819$ & $20,040 \pm 1,743$ & $6,895 \pm 776$ & $12,456 \pm 1,228$ \\
$65 \%$ & $2,559 \pm 225$ & $6,088 \pm 663$ & $2,535 \pm 320$ & $3,727 \pm 396$ \\
\hline
\end{tabular}

Table 3. Morphological characteristics of Zoysia grass

\begin{tabular}{lcccccccc}
\hline $\begin{array}{c}\text { Zoysia sp. } \\
\text { cultivar }\end{array}$ & $\begin{array}{c}\text { Leaf } \\
\text { texture } \\
(\mathrm{mm})\end{array}$ & $\begin{array}{c}\text { Plant } \\
\text { height } \\
(\mathrm{cm})\end{array}$ & $\begin{array}{c}\text { Tiller density } \\
(\text { strand } \\
\left.100 \mathrm{~cm}^{-2}\right)\end{array}$ & $\begin{array}{c}\text { Color } \\
\text { score } \\
(1-10)\end{array}$ & $\begin{array}{c}\text { Recovery } \\
(\%)\end{array}$ & $\begin{array}{c}\text { Dry } \\
\text { weight } \\
\left(\mathrm{kg} \mathrm{m}^{-2}\right)\end{array}$ & $\begin{array}{c}\text { Fresh } \\
\text { weight } \\
\left(\mathrm{kg} \mathrm{m}^{-2}\right)\end{array}$ & $\begin{array}{c}\text { Root } \\
\text { length } \\
(\mathrm{cm})\end{array}$ \\
\hline Bogor & $42 \mathrm{a}$ & $20.8 \mathrm{ab}$ & $38.0 \mathrm{ab}$ & $6.2 \mathrm{a}$ & $62.5 \mathrm{a}$ & $0.26 \mathrm{a}$ & $0.66 \mathrm{a}$ & $17.2 \mathrm{a}$ \\
Jepara & $43 \mathrm{a}$ & $24.1 \mathrm{~b}$ & $34.3 \mathrm{ab}$ & $6.3 \mathrm{a}$ & $61.7 \mathrm{a}$ & $0.30 \mathrm{ab}$ & $0.83 \mathrm{ab}$ & $17.5 \mathrm{a}$ \\
Kebumen & $42 \mathrm{a}$ & $23.0 \mathrm{ab}$ & $47.5 \mathrm{c}$ & $8.5 \mathrm{a}$ & $72.5 \mathrm{abc}$ & $0.24 \mathrm{a}$ & $0.64 \mathrm{a}$ & $19.4 \mathrm{a}$ \\
Kepuh Harjo & $41 \mathrm{a}$ & $20.7 \mathrm{ab}$ & $32.0 \mathrm{ab}$ & $5.8 \mathrm{a}$ & $75.8 \mathrm{bc}$ & $0.36 \mathrm{~b}$ & $0.98 \mathrm{~b}$ & $16.7 \mathrm{a}$ \\
Klaten & $40 \mathrm{a}$ & $18.5 \mathrm{a}$ & $43.0 \mathrm{bc}$ & $7.8 \mathrm{a}$ & $66.7 \mathrm{ab}$ & $0.25 \mathrm{a}$ & $0.61 \mathrm{a}$ & $18.9 \mathrm{a}$ \\
Prambanan & $40 \mathrm{a}$ & $22.2 \mathrm{ab}$ & $32.8 \mathrm{ab}$ & $8.3 \mathrm{a}$ & $78.3 \mathrm{c}$ & $0.25 \mathrm{a}$ & $0.93 \mathrm{a}$ & $17.2 \mathrm{a}$ \\
Solo 1 & $39 \mathrm{a}$ & $21.2 \mathrm{ab}$ & $41.0 \mathrm{bc}$ & $9.5 \mathrm{a}$ & $78.3 \mathrm{c}$ & $0.26 \mathrm{a}$ & $0.69 \mathrm{a}$ & $17.9 \mathrm{a}$ \\
Solo 2 & $28 \mathrm{a}$ & $21.4 \mathrm{ab}$ & $37.3 \mathrm{abc}$ & $6.2 \mathrm{a}$ & $80.8 \mathrm{c}$ & $0.30 \mathrm{ab}$ & $0.73 \mathrm{a}$ & $18.6 \mathrm{a}$ \\
Tabanan Bali & $38 \mathrm{a}$ & $24.3 \mathrm{~b}$ & $28.7 \mathrm{a}$ & $7.7 \mathrm{a}$ & $79.1 \mathrm{c}$ & $0.28 \mathrm{ab}$ & $0.73 \mathrm{a}$ & $18.2 \mathrm{a}$ \\
Ternate & $41 \mathrm{a}$ & $25.1 \mathrm{~b}$ & $47.0 \mathrm{c}$ & $7.7 \mathrm{a}$ & $68.3 \mathrm{ab}$ & $0.28 \mathrm{ab}$ & $0.74 \mathrm{a}$ & $17.3 \mathrm{a}$ \\
\hline
\end{tabular}

Note: Mean in column followed by same letter is not significantly different base on Duncan 0.05

The cultivar of Zoysia spp. has variations on tiller density of grass plants. High density of grass can become an indication that the grass is resistant to disease or other pressures. The Zoysia spp. from Kebumen had the highest number of tillers and significantly different from the Tabanan Bali cultivar which had the least number of tillers. The leaf color indicated the amount of light reflected by the grass (Munandar and Hardjosuwignyo, 1990). In this study, all of the Zoysia cultivars had a bluish-green to dark green color. Cultivar of Zoysia spp. from Kebumen as Z5 I1 treatment has the dark green leaf color. Unruh et al. (2017) states that Zoysia japonica is good due to the color, leaf canopy density and flat leaf stands for lawn care or for sports field. Zoysia leaf color is also dark greener than tall fescue (Festuca amndinaceae Schreb) or cow grass (Cynodon dactylon L.) (Patton and Boyd, 2012).

Shade treatments resulted in significant effect on plant height. The tallest plant height was coming from the shade treatment of $65 \%$ compared to the control which resulted the lowest plant height. Plant height is a measure of the plant which is often observed as an indicator of growth as well as a parameter to measure the effect of the environment or the treatment applied; because plant height is the most easily visible growth measure (Sitompul and Guritno, 1995). Beard et al. (2014) reported that Zoysia grass is tolerant of shade and can be grown in humid and hot areas. In this study the higher plant growth was coming from the higher shade treatment. Light is associated with the work of the auxin hormone, where the activity of the auxin hormone is driven by light. In sufficient light conditions the auxin work optimal thus spur cell division and elongation (Mulyono, 2012).

Table 4 shows the uniformity of Zoysia $s p$. which was viewed from the leaf texture, color and density variables. On average Zoysia $s p$. has uniformity level of 3.67-5.83; thus, belong to low to moderate uniformity. Cultivars which has the highest uniformity were Jepara, Kebumen and Tabanan Bali. The lowest uniformity cultivar was from Klaten. The presence of weeds, damage by diseases and irregular growth properties decreases the grass quality. Differences in density, texture, species composition, color, height of mowing and other properties determine the uniformity. 
Table 4 showed that increased in shading significantly resulted in the decrease of fresh and dry weight before and after mowing and increased plant height and recovery time. However, results showed that shading didn't affect the root length. Table 5 showed that in shade-net $65 \%$ the all cultivars in each mowing has no effect to the plant height, but in shade-nets $25 \%$ the mowing effected height of plant. These results showed that mowing has more effect on height of Zoysia in minimum shading.
Table 5 showed that frequent mowing has more effect to plant height, recovery time and plant dry weight. The increase in shading in mowed grass resulted in an increase of plant height and decreased the plant dry weight while not affecting the plant recovery time (Table 6). The shade treatments resulted significant difference to the recovery time of Zoysia sp. grass. According to Dhika (2014), the function of shading is to obtain optimal light for the shaded plants so that the plant does not experience death from getting too much light.

Table 4. Characteristics of Zoysia grass in different shading

\begin{tabular}{rcccccccc}
\hline Shading & $\begin{array}{c}\text { Fresh } \\
\text { weight } \\
\left(\mathrm{kg} \mathrm{m}^{-2}\right)\end{array}$ & $\begin{array}{c}\text { Dry } \\
\text { weight } \\
\left(\mathrm{kg} \mathrm{m}^{-2}\right)\end{array}$ & $\begin{array}{c}\text { Dry weight } \\
\text { after mowing }\end{array}$ & $\begin{array}{c}\text { Root } \\
\text { length } \\
(\mathrm{cm})\end{array}$ & $\begin{array}{c}\text { Root dry } \\
\text { weight }\end{array}$ & $\begin{array}{c}\text { Recovery } \\
(\%)\end{array}$ & $\begin{array}{c}\text { Recovery } \\
\text { after } \\
\text { mowing }\end{array}$ & $\begin{array}{c}\text { Plant height } \\
\text { without mowing } \\
(\mathrm{cm})\end{array}$ \\
\hline $0 \%$ & $0.38 \mathrm{c}$ & $0.48 \mathrm{c}$ & $0.16 \mathrm{c}$ & $17.97 \mathrm{a}$ & $4.68 \mathrm{~b}$ & $72.1 \mathrm{~b}$ & $67.3 \mathrm{a}$ & $14.59 \mathrm{a}$ \\
$25 \%$ & $0.27 \mathrm{~b}$ & $0.38 \mathrm{~b}$ & $0.13 \mathrm{~b}$ & $16.34 \mathrm{a}$ & $3.96 \mathrm{ab}$ & $67.3 \mathrm{a}$ & $72.0 \mathrm{~b}$ & $19.55 \mathrm{~b}$ \\
$65 \%$ & $0.16 \mathrm{a}$ & $0.22 \mathrm{a}$ & $0.11 \mathrm{a}$ & $19.34 \mathrm{a}$ & $2.34 \mathrm{a}$ & $78.0 \mathrm{c}$ & $78.0 \mathrm{c}$ & $32.28 \mathrm{c}$ \\
\hline
\end{tabular}

Note: Mean in column followed by same letter is not significantly different base on Duncan 0.05

Table 5. Plant height of Zoysia grass in different shading and mowing

\begin{tabular}{|c|c|c|c|c|c|c|c|c|c|}
\hline \multirow{3}{*}{ Zoysia cultivar } & \multicolumn{9}{|c|}{ Plant height $(\mathrm{cm})$} \\
\hline & \multicolumn{3}{|c|}{ Control } & \multicolumn{3}{|c|}{ Shading $25 \%$} & \multicolumn{3}{|c|}{ Shading $65 \%$} \\
\hline & Mow 1 & Mow 2 & Mow 3 & Mow 1 & Mow 2 & Mow 3 & Mow 1 & Mow 2 & Mow 3 \\
\hline Bogor & $8.65 a$ & $7.80 \mathrm{ab}$ & $7.60 \mathrm{a}$ & $8.40 \mathrm{abc}$ & $7.30 \mathrm{abc}$ & $6.85 b$ & $6.75 \mathrm{a}$ & $9.50 \mathrm{a}$ & $9.60 \mathrm{a}$ \\
\hline Jepara & $9.20 \mathrm{a}$ & $8.75 b$ & $7.60 \mathrm{a}$ & $8.10 \mathrm{ab}$ & $7.75 a b c$ & $7.25 b c$ & $13.10 \mathrm{a}$ & $11.30 \mathrm{a}$ & $9.25 \mathrm{a}$ \\
\hline Kebumen & $8.05 \mathrm{a}$ & 7.30ab & $7.00 \mathrm{a}$ & $8.90 b c$ & $8.20 b c$ & $7.75 \mathrm{~cd}$ & $13.00 \mathrm{a}$ & $12.05 \mathrm{a}$ & $9.00 \mathrm{a}$ \\
\hline Kepuh Harjo & $7.15 \mathrm{a}$ & $5.70 \mathrm{ab}$ & $5.90 \mathrm{a}$ & $8.55 \mathrm{abc}$ & $8.05 \mathrm{abc}$ & $7.75 \mathrm{~cd}$ & $12.10 \mathrm{a}$ & $10.25 \mathrm{a}$ & $10.25 \mathrm{a}$ \\
\hline Klaten & $8.80 \mathrm{a}$ & $7.70 \mathrm{a}$ & $7.50 \mathrm{a}$ & $8.45 a b c$ & $7.00 \mathrm{a}$ & $6.85 \mathrm{~b}$ & $11.65 \mathrm{a}$ & $10.05 \mathrm{a}$ & $7.00 \mathrm{a}$ \\
\hline Prambanan & $7.25 \mathrm{a}$ & $6.60 \mathrm{ab}$ & $6.20 \mathrm{a}$ & $7.60 \mathrm{a}$ & $7.25 \mathrm{abc}$ & $7.10 b c$ & $12.45 \mathrm{a}$ & $10.70 \mathrm{a}$ & $9.75 \mathrm{a}$ \\
\hline Solo 1 & $7.60 \mathrm{a}$ & $6.95 \mathrm{ab}$ & $6.50 \mathrm{a}$ & $7.60 \mathrm{a}$ & $7.05 \mathrm{ab}$ & $6.00 \mathrm{a}$ & $12.60 \mathrm{a}$ & $9.75 \mathrm{a}$ & $9.75 \mathrm{a}$ \\
\hline Solo 2 & $8.30 \mathrm{a}$ & $7.60 \mathrm{a}$ & $7.05 \mathrm{a}$ & $8.25 \mathrm{abc}$ & $7.20 \mathrm{abc}$ & $7.00 \mathrm{~b}$ & $11.70 \mathrm{a}$ & $9.90 \mathrm{a}$ & $9.05 \mathrm{a}$ \\
\hline Tabanan Bali & $8.65 \mathrm{a}$ & 7.40ab & $7.25 \mathrm{a}$ & $8.00 \mathrm{ab}$ & $7.65 \mathrm{abc}$ & $7.10 b c$ & $12.05 \mathrm{a}$ & $11.20 \mathrm{a}$ & $10.25 \mathrm{a}$ \\
\hline Ternate & $7.00 \mathrm{a}$ & $6.65 \mathrm{ab}$ & $6.10 \mathrm{a}$ & $9.10 \mathrm{c}$ & $8.30 \mathrm{c}$ & $8.00 \mathrm{~d}$ & $12.30 \mathrm{a}$ & $10.65 \mathrm{a}$ & $11.50 \mathrm{a}$ \\
\hline
\end{tabular}

Note: Mean in column followed by same letter is not significantly different base on Duncan 0.05

Table 6. Effect of mowing on the plant height, recovery and dry weight

\begin{tabular}{cccccccccc}
\hline \multirow{3}{*}{ Mowing } & \multicolumn{7}{c}{ Shading } \\
\cline { 2 - 9 } & \multicolumn{1}{c}{ Control } & $25 \%$ & $65 \%$ & Control & $25 \%$ & $65 \%$ & Control & $25 \%$ & $65 \%$ \\
\cline { 2 - 9 } & \multicolumn{2}{c}{ Plant height (cm) } & \multicolumn{2}{c}{ Recovery $(\%)$} & Plant dry & weight $\left(\mathrm{g} 100 \mathrm{~cm}^{-2}\right)$ \\
\hline Mowing 1 & $8.07 \mathrm{a}$ & $8.30 \mathrm{a}$ & $11.77 \mathrm{a}$ & $76.50 \mathrm{a}$ & $76.75 \mathrm{a}$ & $77.25 \mathrm{~b}$ & $0.157 \mathrm{~b}$ & $0.1305 \mathrm{~b}$ & $0.115 \mathrm{a}$ \\
Mowing 2 & $7.25 \mathrm{~b}$ & $7.58 \mathrm{~b}$ & $10.54 \mathrm{ab}$ & $77.50 \mathrm{a}$ & $76.75 \mathrm{a}$ & $69.00 \mathrm{a}$ & $0.122 \mathrm{a}$ & $0.1050 \mathrm{a}$ & $0.082 \mathrm{a}$ \\
Mowing 3 & $6.87 \mathrm{~b}$ & $7.17 \mathrm{c}$ & $9.54 \mathrm{~b}$ & $75.00 \mathrm{a}$ & $75.00 \mathrm{a}$ & $71.25 \mathrm{ab}$ & $0.158 \mathrm{~b}$ & $0.1135 \mathrm{ab}$ & $0.094 \mathrm{a}$ \\
\hline
\end{tabular}

Note: Mean in column followed by same letter is not significantly different base on Duncan 0.05

Table 7 showed that shade net $65 \%$ resulted the lowest grass recovery and the $25 \%$ shade net resulted high rate of recovery. The cultivar from Bali, Prambanan, Solo I and Solo II had an average recovery rate of $79.17 \%$ to $80.83 \%$ for 14 days. This suggested that within 14 days the grass cultivars can recover after mowing of $0.25 \mathrm{~cm}$ from the plant height. The lowest recovery rate was on the cultivar originated from Jepara with an average of $61.67 \%$. The shade net $25 \%$ (I1) 
resulted in the highest plant dry weight at the first mowing of $0.33 \mathrm{~kg} \mathrm{~m}^{-2}$; while the shade treatment of $65 \%$ (I2) resulted the smallest yield of $0.22 \mathrm{~kg} \mathrm{~m}^{-2}$. According to Turgeon (2002), dry weight of grass can be a benchmark of grass growth that is affected by maintenance, irrigation, fertilization and other environmental factors. This study showed that the highest dry weight was obtained by the cultivar from Sleman, followed by cultivar from Jepara and Solo II, whereas the lowest dry weight of grass was obtained from the cultivar from Kebumen.

Table 7. Effect of shading on the plant height, recovery and dry weight

\begin{tabular}{|c|c|c|c|c|c|c|c|c|c|}
\hline \multirow{3}{*}{ Mowing } & \multicolumn{9}{|c|}{ Mowing } \\
\hline & 1 & 2 & 3 & 1 & 2 & 3 & 1 & 2 & 3 \\
\hline & \multicolumn{3}{|c|}{ Plant height $(\mathrm{cm})$} & \multicolumn{3}{|c|}{ Recovery (\%) } & \multicolumn{3}{|c|}{ Plant dry weight $\left(\mathrm{g} 100 \mathrm{~cm}^{-2}\right)$} \\
\hline Control & $8.07 \mathrm{a}$ & $7.25 \mathrm{a}$ & $6.87 \mathrm{a}$ & $76.50 \mathrm{a}$ & $69.00 \mathrm{a}$ & $71.25 \mathrm{a}$ & $0.158 b$ & $0.122 \mathrm{c}$ & $0.158 b$ \\
\hline Shade $25 \%$ & $8.30 \mathrm{a}$ & $7.58 \mathrm{a}$ & $7.17 \mathrm{a}$ & $76.75 \mathrm{a}$ & $76.75 b$ & $75.05 \mathrm{a}$ & $0.131 \mathrm{a}$ & $0.105 b$ & $0.114 \mathrm{ab}$ \\
\hline Shade $65 \%$ & $11.77 \mathrm{~b}$ & $10.54 b$ & $9.54 b$ & $77.25 \mathrm{a}$ & $77.50 \mathrm{~b}$ & $75.00 \mathrm{a}$ & $0.115 \mathrm{a}$ & $0.082 \mathrm{a}$ & $0.094 \mathrm{a}$ \\
\hline
\end{tabular}

Note: Mean in column followed by same letter is not significantly different base on Duncan 0.05 ; shading $25 \%$ was not significant different to the control

The shading also resulted in significant difference in the variable of fresh weight of grass. The highest plant fresh weight after the 1st mowing was obtained by the cultivar from Sleman with $0.98 \mathrm{~kg} \mathrm{~m}^{-2}$ and the lowest yields was from cultivar from Klaten with $0.61 \mathrm{~kg} \mathrm{~m}^{-2}$. Mayasari et al. (2012) reported that low plant fresh weight could occur from the inadequate solar irradiation due to blockage by a fairly closed canopy cover. The shading treatments have no significant effect on grass root length but affected the root dry weight (Table 4). Emmons (2000) stated that long and bushy roots facilitate grass to absorb water and nutrients on the deeper surface of the soil thus promote the grass growth. Control resulted in higher root dry weight and significantly different from $65 \%$ shade net treatment. The growth and development of good roots can lead to canopy growth through stolon and rhizome roots resulting in more tiller yields with finer leaf texture, faster recovery and longer land cover. According to Emmons (2000), soil conditions have a great influence on the grass roots depth. Long, dense roots allow the grass to absorb water and nutrients on the deeper surface of the soil and affect the resistance to drought.

\section{CONCLUSIONS}

Cultivars of Zoysia grass and shade treatments affected the turf uniformity and plant dry weight. Shading and frequent mowing affected the plant height where in low shading the mowing has more effect on plant height. In heavy shading the mowing has no effect to the plant height. An increase in the shading level in mowed grass decreased plant dry weight. The high yield of plant dry weight was obtained by the cultivars from Sleman and Jepara; whereas the low yield of plant dry weight was obtained by the cultivar from Kebumen.

\section{ACKNOWLEDGEMENT}

The authors would like to gratefully acknowledged Reza Hatami for maintaining the turfgrass and The Indonesian Ministry of Research, Technology and Higher Education (RISTEKDIKTI) for the fund support in financial year of 2014-2015.

\section{REFERENCES}

Alvarenga, A. A., Evaristo, M. C., Erico, C., Lima, J., \& Marcelo, M. M. (2004). Effects of different light levels on the initial growth and photosynthetic of Croton urucurana Baill in Southeastern Brazil. Revista Árvore, 27, 5357. http://dx.doi.org/10.1590/S0100-6762200 3000100007

An, S., Darboux, F., \& Cheng, M. (2013). Revegetation as an efficient means of increasing soil aggregate stability on the Loess Plateau (China). J. Geoderma, 209-210, 7585. https://doi.org/10.1016/j.geoderma.2013.0 5.020

Anderson, S. J. (2000). Taxonomy of Zoysia (Poaceae): Morphological and molecular variation. Thesis. Texas A \& M University College Station TX. Retrieved from http:// grassworld.myspecies.info/en/content/taxono my-zoysia-poaceae-morphological-and- 
molecular-variation

Asriyanti, W., \& Irmasari. (2015). Pengaruh berbagai intensitas naungan terhadap pertumbuhan semai eboni (Diospyros celebica Bakh.). Jurnal Warta Rimba, 3(2), 103-110. http://jurnal.untad.ac.id/jurnal/index.php/Wart aRimba/article/view/6356

Audina, N. M., Maxiselly, Y., \& Rosniawaty, S. (2016). Pengaruh kerapatan naungan dan frekuensi penyiraman terhadap pertumbuhan bibit kemiri sunan (Reutealis trisperma (BLANCO) Airy Shaw). Jurnal Kultivasi, 15(2), 70-73. https://doi.org/10.24198/kulti vasi.v15i2.11901

Baldwin, C., Liu, H., McCarty, L. B., Rajapakse, N. C., Luo, H., \& Toler, J. E. (2007). Altered light spectral qualities impacts on warmseason turfgrass growth and development. USGA Turfgrass and Environmental Research Online, 7(9), 1-12. Retrieved from https:// www.usga.org/content/dam/usga/pdf/importe d/64.pdf or https://usgatero.msu.edu/v07/n09 .pdf

Beard, J. B. (1973). Turfgrass science and culture. Englewood Cliffs, NewJersey, USA: Prentice Hall, Inc. Retrieved from https://scholar. google.com/scholar_lookup?title=Turfgrass $\%$ $3 \mathrm{~A}+$ science+and+culture \&author $=$ Beard $\% 2 \mathrm{C}$ +James+B\&publication_year=1972

Beard, J. B. (1997). Shade stresses and adaptation mechanisms of turf grasses. International Turfgrass Society Research Journal, 8, 11861195. Retrieved from http://turfsociety.com/ itsjournal/vol08toc.pdf

Beard, J. B., Beard, H. J., \& Beard, J. C. (2014). Turfgrass history and literature: Lawns, sports, and golf. East Lansing, USA: Michigan State Univ. Press. Retrieved from https:// scholar.google.co.id/scholar?cluster $=1160192$ $1130496702050 \& \mathrm{hl}=\mathrm{id} \&$ as_sdt=2005\&sciodt $=0,5 \&$ scioq $=$ Turfgrass + history+and+literatur e:+Lawns,+sports,+and+golf.

Bradley, S., Henry, G. M., \& Dick, L. (2009). Evaluation of Zoysiagrass genotypes for shade tolerance. HortScience, 44(5), 14471451. https://doi.org/10.21273/HORTSCI.44. 5.1447

Celesti-Grapow, L., Alessandrini, A., Arrigoni, P., Banfi, E., Bernardo, L., Bovio, M., ... \&
Blasi, C. (2009). Inventory of the non-native flora of Italy. Plant Biosystems, 143(2), 386430. https://doi.org/10.1080/11263500902722 824

Dhika, D. (2014). Shade making. Journal of Basic Practices in Agronomy. Department of Agro Technology. Faculty of Agriculture, North Sumatra Islamic University.

Dudeck, A., \& Peacock, C. (1992). Shade and turfgrass culture. In Turfgrass (eds Waddington, D. V., Carrow, R. N., \& Shearman, R. C.), 32, pp. 269-284. https://doi. org/10.2134/agronmonogr32.c8

Emmons, R. (2000). Turfgrass science and management (Third). New York, USA: Cengange Delmar Learning. Retrieved from https://books.google.co.id/books/about/Turfgr ass_Science_and_Management.html?id=e3Il AQAAMAAJ\&redir_esc $=y$

Engelke, M. C., \& Anderson, S. (2003). Zoysiagrasses (Zoysia spp.). In: Casler M.D., \& Duncan, R. R. (eds.). Turfgrass biology genetics and breeding. Hoboken, New Jersey, USA: John Wiley \& Sons. pp. 271-285. Retrieved from https://scholar.google.com/ scholar_lookup?title=Turfgrass+biology $\% 2 \mathrm{C}$ +genetics $\% 2 \mathrm{C}+$ and+breeding\&author $=$ M.C.+ S.+Engelke\%2C+Anderson\%2C\&author $=\mathrm{M}$. D.+R.R.+Casler+Duncan\&publication_year= 2003\&pages $=271-286$

Faridah, E. (1996). Effects of light intensity, mycorrhiza and charcoal powder on natural growth of Rybalanops sp. Research Bulletin, Fahutan UGM Yogyakarta, 29, 21-28. Retrieved from http://i-lib.ugm.ac.id/jurnal/ detail.php?dataId=3782

Fry, J. D., \& Huang, B. (2004). Applied turfgrass science and physiology. Hoboken, New Jersey, USA: John Wiley \& Sons.. Retrieved from https://www.wiley.com/en-us/Applied+Turfgr ass+Science+and+Physiology-p-9780471472 704

Fry, J. D., Zhang, Q., Okeyo, D., Engelke, M., \& Genovesi, D. (2008). Improved Zoysia cultivar could have use in transition zone. Turfgrass Trends Golfdom Cleveland $\mathrm{OH}$, 60-61. http://archive.lib.msu.edu/tic/golfd/article/200 8aug58.pdf

Lakshmipathy, M., Prasad, K. V., Manjaiah, K. 
M., Janakiram, T., \& Namita. (2018). Performance of turfgrasses on a clay based simulated cricket pitch under varied levels of soil compaction and ABA. Indian Journal of Horticulture, 75(3), 512-516. http://dx.doi. org/10.5958/0974-0112.2018.00086.5

Livesley, S. J., Ossola, A., Threlfall, C. G., Hahs, A. K., \& Williams, N. S. G. (2016). Soil carbon and carbon/nitrogen ratio change under tree canopy, tall grass, and turf grass areas of urban green space. Journal of Environmental Quality, 45(1), 215-223. https://doi.org/10.2134/jeq2015.03.0121

Mayasari, A., Kinho, J., \& Suryawan, A. (2012). The association of ebony (Diospyros spp.) and dominant tree species in Tangkoko Nature Reserve North Sulawesi. Manado Forestry Research Institute Manado BPK Information, 2(1), 55-71. Retrieved from https://www. forda-mof.org/files/POTENSI_PERMUDAA N_ALAMI_JENIS-JENIS_EBONI.pdf

Monteiro, J. A. (2017). Ecosystem services from turfgrass landscapes. Urban Forestry \& Urban Greening, 26, 151-157. http://dx.doi.org/ 10.1016/j.ufug.2017.04.001

Mulyono, D. (2012). Pengaruh kombinasi intensitas naungan dengan zat pengatur tumbuh indole butiric acid (IBA), naphthalene acetic acid (NAA), dan vitamin B1 dalam aklimatisasi pertumbuhan bibit gaharu (Aquilaria beccariana). Jurnal Sains dan Teknologi Indonesia, 14(3), 167-173. https://doi.org/10.29122/jsti.v14i3.922

Munandar, A., \& Hardjosuwignyo, S. (1990). Landscape grass. Bogor Institute of Agriculture.

Okeyo, D. O., Fry, D. J., Bremer, D. J., Chandra, A., Genovesi, A. D., \& Engelke, M. C. (2014). Stolon growth and tillering of experimental zoysiagrasses in shade. HortScience, 49(11), 1444-1448. https://doi.org/10.21273/HORTS CI.46.10.1418

Pantilu, L. I., Mantiri, F. R., Ai, N. S., \& Pandiangan, D. (2012). Respons morfologi dan anatomi kecambah kacang kedelai (Glycine max (L.) Merill) terhadap intensitas cahaya yang berbeda. Journal of Bioslogos, 2(2), 81-87. https://doi.org/10.35799/jbl.2.2. 2012.1044
Patton, A. (2009). Growing turfgrass in shade. Agriculture and Natural Resources. Arkansas University, Division of Agriculture. Retrieved from https://www.uaex.edu/publications/PDF /FSA-6140.pdf

Patton, A., \& Boyd, J. (2012). Choosing a grass for Arkansas Lawns. Agriculture and Natural Resources. Arkansas University, Division of Agriculture. Retrieved from https://www. uaex.edu/publications/PDF/FSA-2112.pdf

Peterson, K., Fry, J. D., \& Bremer, D. J. (2014). Growth responses of Zoysia spp. under tree shade in the Midwestern United States. HortScience, 49(11), 1444-1448. https://doi. org/10.21273/HORTSCI.49.11.1444

Qian, Y. L., Engelke, M. C., Foster, M. J. V., \& Reynolds, S. (1998). Trinexapac-ethyl restricts shoot growth and improves quality of 'Diamond' zoysiagrass under shade. HortScience, 33(6), 1019-1022. https://doi. org/10.21273/HORTSCI.33.6.1019

Rahayu, Mujiyo, Syamsiyah, J., Ji, B. E., Min, C. S., Mo, Y. G., \& Soo, C. J. (2016). Survey on native Zoysiagrass in Indonesia: Its spread and characteristics. ARPN Journal of Engineering and Applied Sciences, 11(21), 12534-12537. http://www.arpnjournals.org/jeas/research_pa pers/rp_2016/jeas_1116_5267.pdf

Rahayu, Syamsiyah, J., \& Nikmatus, L. (2020). Aggregate stability of Alfisols root zone upon turfgrass treatment. Sains Tanah Journal of Soil Science and Agroclimatology, 17(1), 5056. https://doi.org/10.20961/stjssa.v17i1.404 55

Sitompul, S. M., \& Guritno, B. (1995). Effect of shading, mycorrizha inoculated and organic matter on the growth of Hopea gregaria seedling. Buletin Penelitian Fahutan UGM Yogyakarta, 28, 18-27. Retrieved from http:// i-lib.ugm.ac.id/jurnal/detail.php?dataId=3727

Sladek, B. S., Henry, G. M., \& Auld, D. L. (2009). Evaluation of zoysia grass genotypes for shade tolerance. HortScience, 44(5), 1447-1451. https://doi.org/10.21273/HORTSCI.44.5.1447

Syers, J. K., Nyamudeza, P., \& Ahenkorah, Y. (2001). Sustainable nutrient management of Vertisols. In. Syers, J. K., Penning de Vries, F. W. T., Nyamudeza, P. Editor(s). The Sustainable Management of Vertisols. New 
York, USA: CABI, pp. 43-55. http://dx.doi. org/10.1079/9780851994505.0043

Turgeon, A. J. (2002). Turfgrass management (6th Edition). Englewood Cliffs, New Jersey, USA: Pearson Education, Inc. Retrieved from https://scholar.google.co.id/scholar?cluster=1 $2719851228961588269 \& \mathrm{hl}=\mathrm{id} \& \mathrm{as} \_\mathrm{sdt}=2005$ $\&$ sciodt $=0,5 \&$ scioq $=$ TURGEON+Turfgrass + Management. +2002

Unruh, J. B., Trenholm, L. E., \& Cisar, J. L. (2017). Zoysia grasses for Florida lawns. Florida University. Retrieved from http:// dickersonlandscaping.com/zoysiagrass
Wherley, B. G., Skulkaew, P., Chandra, A., Genovesi, A. D., \& Engelke, M. C. (2011). Low-input performance of zoysiagrass (Zoysia spp.) cultivars maintained under dense tree shade. Hort Science, 46(7), 1033-1037. https://doi.org/10.21273/HORTSCI.46.7.1033

Wijayanto, N., \& Nurunnajah. (2012). Intensitas cahaya, suhu, kelembaban dan perakaran lateral mahoni (Swietenia macrophylla King.) di RPH Babakan Madang, BKPH Bogor, KPH Bogor. Journal of Tropical Silviculture, 3(1), 8-13. Retrieved from https://journal.ipb.ac.id/ index.php/jsilvik/article/view/5389 